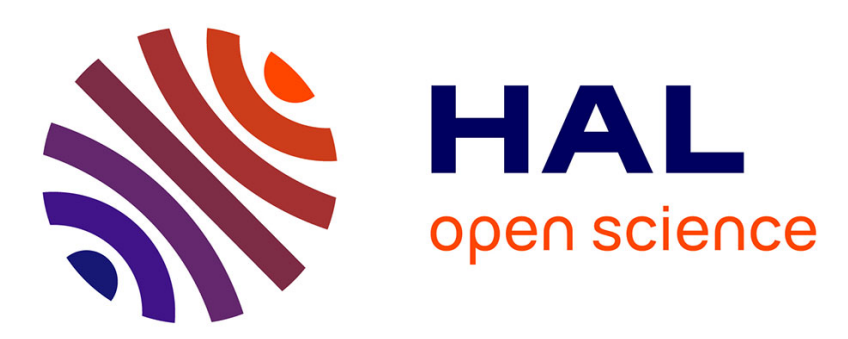

\title{
The interplay of language-internal variation and contact influence in language change
}

\author{
Brigitte Pakendorf
}

\section{To cite this version:}

Brigitte Pakendorf. The interplay of language-internal variation and contact influence in language change. In Isabelle Léglise, Claudine Chamoreau. The Interplay of Variation and Change in Contact Settings, John Benjamins, pp.199-227, 2013. hal-02012598

\section{HAL Id: hal-02012598 \\ https://hal.univ-lyon2.fr/hal-02012598}

Submitted on 16 Jul 2020

HAL is a multi-disciplinary open access archive for the deposit and dissemination of scientific research documents, whether they are published or not. The documents may come from teaching and research institutions in France or abroad, or from public or private research centers.
L'archive ouverte pluridisciplinaire HAL, est destinée au dépôt et à la diffusion de documents scientifiques de niveau recherche, publiés ou non, émanant des établissements d'enseignement et de recherche français ou étrangers, des laboratoires publics ou privés. 


\section{John Benjamins Publishing Company}

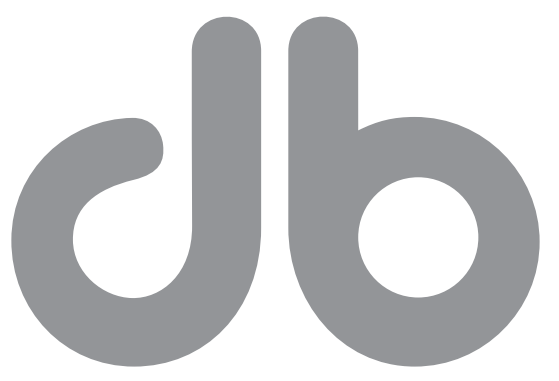

This is a contribution from The Interplay of Variation and Change in Contact Settings. Edited by Isabelle Léglise and Claudine Chamoreau.

(c) 2013. John Benjamins Publishing Company

This electronic file may not be altered in any way.

The author(s) of this article is/are permitted to use this PDF file to generate printed copies to be used by way of offprints, for their personal use only.

Permission is granted by the publishers to post this file on a closed server which is accessible to members (students and staff) only of the author's/s' institute, it is not permitted to post this PDF on the open internet.

For any other use of this material prior written permission should be obtained from the publishers or through the Copyright Clearance Center (for USA: www.copyright.com). Please contact rights@benjamins.nl or consult our website: www.benjamins.com Tables of Contents, abstracts and guidelines are available at www.benjamins.com 


\title{
The interplay of language-internal variation and contact influence in language change ${ }^{\star}$
}

\author{
Brigitte Pakendorf \\ CNRS, DDL, Dynamique Du Langage, Lyon, France
}

In this paper, evidence is presented for the important role played by languageinternal variation in situations of contact-induced change. Such language-internal variation can function in two ways, through "frequential copying" on the one hand and "contact-induced exaptation" on the other. In frequential copying, an infrequently used construction in the recipient language can increase in frequency and ultimately even become the norm, if there is a similar construction in the model language. In contact-induced exaptation, constructional variants that differ in meaning from the default construction can provide the material basis for the grammaticalization of new constructions. This interplay of internal variation and external influence is exemplified with data from several northern Eurasian languages.

Keyword: language-internal variation; frequential copying; contact-induced exaptation; frequency; northern Eurasian languages

\section{Introduction}

Ever since the publication of Thomason \& Kaufman's seminal study on language contact (Thomason \& Kaufman 1988), an ever-growing number of publications has dealt with the linguistic changes brought about through contact with neighboring languages (see e.g. Haase 1992; Aikhenvald 1996; Ross 1996; and the individual contributions to Aikhenvald \& Dixon 2006; and Matras \& Sakel 2007,

\footnotetext{
* The data discussed in this paper were gathered and analyzed while I was affiliated with the MPI for Evolutionary Anthropology, Leipzig, Germany, and were first presented in Pakendorf (2007) and partly in Pakendorf (2010), albeit in a different context. A subset of the data was discussed in the present framework of the interplay of language-internal variation and contact-induced change at the workshop on "Language contact and morpho-syntactic variation and change" in Paris, September 2007. I thank Bernard Comrie, Frederik Kortlandt, and members of the workshop for helpful discussion, as well as an anonymous reviewer for pointing out carelessly worded arguments.
} 
to name but a few). The range of contact-induced changes detected in such studies is broad, extending from the copying ${ }^{1}$ of individual lexemes to near-complete structural convergence (e.g. Gumperz \& Wilson 1971).

However, as will be demonstrated in this paper, contact influence does not only lead to the creation of new items through the copying of meaning, form, or structure, but can also lead to changes in the frequency of use of constructions already existing in the language. This phenomenon has been called "frequential copying" by Johanson (1999:52, 2002:306) and "enhancement" by Aikhenvald (2002:238), while Heine \& Kuteva talk about minor use patterns becoming major use patterns through contact: "A widely observable process triggered by language contact concerns infrequently occurring, minor use patterns that are activated because there is a model provided by another language" (Heine \& Kuteva 2005: 50). An example they discuss are the West Rumelian Turkish dialects spoken in Macedonia. In Standard Turkish, which is fairly consistently verb-final, an infrequent, pragmatically-marked syntactic pattern permits the placement of the verb in non-final position. In the West Rumelian Turkish dialects, however, verbmedial syntactic patterns occur quite frequently and have lost their pragmatic markedness, due to frequential copying from neighboring verb-medial languages such as Macedonian. The increase in frequency of an infrequently used construction leads to a corresponding decrease in frequency and occasionally total loss of the construction that previously formed the major pattern (cf. Johanson 2008). Thus, language-internal variation can play an important role in contact-induced language change, by providing access to constructions that can be activated by exposure to the neighboring language. A further way in which language-internal variation can interact with external contact influence is by providing the material basis for grammaticalization processes triggered by structures found in the contact language. Both types of interaction between language-internal variation and contact influence will be illustrated here with several examples of change in Sakha (Yakut), Evenki, and some Mongolic languages, all spoken in northern Eurasia.

1. A brief note on terminology: there is a lack of stringency surrounding the term "borrowing," which is used to refer to the copying of form-meaning pairs as opposed to the copying of structure (Weinreich 1953); to copies entering a language that is maintained as opposed to copies entering a language through shift (Thomason \& Kaufman 1988); and to the transfer of copies from a bilingual speaker's non-dominant language into his/her dominant language (van Coetsem 1988, cited from Winford 2005). Therefore, I prefer to use the term "copying" to refer to all processes of contact-induced change, be they the transfer of actual form-meaning pairs (substance copies) or the transfer of structural patterns (schematic copies). The language that provides the model for the copy is the model language; the language that makes the copy is the recipient language (cf. Pakendorf 2007:44-46).

(C) 2013. John Benjamins Publishing Company

All rights reserved 
An overview of the genealogical affiliation and approximate geographic location of the languages mentioned in the paper is given in Appendix 1.

Sakha is a divergent Turkic language spoken in large areas of northeastern Siberia by cattle and horse pastoralists. The Sakha are relatively recent immigrants to their current area of settlement, having migrated to the north from the shores of Lake Baikal approximately 600-700 years ago (Gogolev 1993:61, 88f; Alekseev 1996: 46). Their language, though indubitably Turkic, contains a large number of Mongolic lexical copies, as well as some copied Mongolic suffixes (Kałużyński 1962; Pakendorf \& Novgorodov 2009). This implies that the Sakha ancestors must have been in close contact with speakers of one or more Mongolic languages, most probably during the period of the Mongol Empire. In addition, the language has undergone some structural change under Evenki influence (Pakendorf 2007:303-305).

Evenki is a Northern Tungusic language spoken by widely dispersed groups of nomadic hunters and reindeer herders. Together with its close relative Ėven it is one of the geographically most widely distributed languages, spoken from east of the Yenisei to the coast of the Sea of Okhotsk, and from the southern parts of the Taimyr Peninsula to the Amur river (Atknine 1997: 110). Due to their widespread area of settlement, Evenks are in contact with speakers of the isolate language Ket, the Samoyedic language Nenets, and the Turkic languages Dolgan (a close relative of Sakha) and Sakha in their northern and western territories, with Buryats in the south, and with speakers of Southern Tungusic dialects as well as with Ėvens in the eastern and southeastern range of their settlement (Wurm 1996: Map 109). They may thus have played the role of "vectors of diffusion" (Anderson 2006: 294) of change in Siberian languages.

Modern-day Mongolic languages are very closely related, since they arose out of a unified language imposed on the Mongol Empire by Genghis Khan at the beginning of the thirteenth century (Janhunen 1998: 203). The diversification of the Mongolic languages may have begun shortly thereafter during the expansion and dispersion of Mongolic-speaking peoples in the Mongol Empire (Janhunen 1996:159, 161), or at a later stage, between the end of the fourteenth and the middle of the sixteenth century, after the Mongol Empire had broken apart (Weiers 1986:37). The bulk of the Mongolic languages are divided into two main branches, West Mongolic and East Mongolic. The West Mongolic languages Oirat and Kalmyk developed their own written script in the seventeenth century, Written Oirat, which was in use until the twentieth century (Weiers 1986: 42). The East Mongolic languages, on the other hand, continued to use Written Mongol as a medium of written communication. This is an exclusively written lect, which was in continued use amongst speakers of most dialects/languages of Mongolic from the thirteenth century onwards (Weiers 1986:31f; Janhunen 2003a: 2 and 
2003b:30). The differences between the modern Mongolic languages are due to the effects of geographical isolation as well as differential substrate and adstrate influences (Weiers 1986:38; Janhunen 1996: 161). Buryat, which is spoken to the east and west of Lake Baikal in southern Siberia, comprises the northern branch of the East Mongolic languages (Weiers 1986:42). It is spoken by cattle and horse pastoralists, who may have assimilated some of the Turkic-speaking ancestors of the Sakha, as well as Evenks, in the course of their history (Nimaev 2004:20; Buraev \& Šagdarov 2004: 228-229).

The role that language-internal variation in conjunction with external contact-induced influence can play in language change will be discussed on the basis of four examples of changes, two in the nominal case system and two in the verbal system. Section 2 describes the loss of the genitive case in Sakha, Section 3 discusses the shift in the local case system of Evenki, while the divergent development of subject agreement marking in Mongolic languages is presented in Section 4, and the development of a future imperative mood in Sakha is discussed in Section 5. The paper ends with a discussion and some brief conclusions in Section 6.

\section{The loss of the genitive case in Sakha}

\subsection{Possessive constructions in Turkic languages}

One of the salient differences between Sakha and its Turkic relatives (with the exception of Dolgan) is the lack of the genitive case in Sakha. In possessive constructions in Sakha, the head takes suffixes agreeing in person and number with its modifier, and the modifier remains unmarked $(1 \mathrm{a}, \mathrm{b}) .{ }^{2}$ However, a remnant of the old genitive case is retained in sequences of 3 sg possessors, in which it marks the intermediate noun (1c).

(1) Sakha (Pakendorf, narrative field data, 2002) ${ }^{3}$
a. $\min$ die- $m$
tah-ïgar
die ba:r
1sG house-POss.1sg outside-DAT.3SG house existence
"Next to my house there is a house"
2. Note that suffixes in Sakha can have fairly variable surface forms, since consonants undergo assimilation processes across morpheme boundaries, and vowels undergo changes in accordance with vowel harmony rules.

3. Abbreviations used in the glosses are as follows: $1=$ first person; $2=$ second person; 3 = third person; $\mathrm{ABL}=$ ablative; $\mathrm{ACC}=$ accusative; $\mathrm{ALL}=$ allative; $\mathrm{ANT} . \mathrm{CVB}=$ anterior converb; CAUS $=$ causative COND $=$ conditional $; \mathrm{DAT}=$ dative $\mathrm{EMPH}=$ emphatic $; \mathrm{FOC}=$ focus $; \mathrm{FUT}=$ future; 


\section{b. hebiet hekereter $r$-e \\ Soviet secretary-Poss.3sG \\ "Secretary of the Soviet" \\ c. oyo tayah-in hurj-ui-ta \\ child clothes-GEN wash-NMLZ-POss.3sG \\ "the washing of the children's clothes"}

In contrast, in the other Turkic languages, while the possessum takes suffixes agreeing with the possessor in person and number, as in Sakha, the possessor in possessive constructions is additionally marked by the genitive case ( $2 \mathrm{a})$. However, in the context of the loss of the Sakha genitive, it is important to note that in addition to genitivally marked constructions, Turkic languages have possessive constructions consisting of an unmarked possessor and marked possessum, the so-called izafet constructions $(2 \mathrm{~b}, \mathrm{c})$. In modern Turkic languages, these express abstract, generic possession as well as part-whole relations; that is, they have a restricted function. This contrasts with the Sakha possessive construction, in which the unmarked possessor is used equally to express actual ownership as well as to express generic possession and part-whole relations.

(2) Turkish (Kornfilt 1997:230) ${ }^{4}$

a. Hasan-in kitab-ı

H.-GEN book-POss.3sG

"Hasan's book"

b. Kazakh (Sovremennyj kazaxskij jazyk 1962:161)

qoy et-i

sheep meat-Poss.3sG

"mutton"

c. Uzbek (Bodrogligeti 2003:77)

boš yorig- $i$

head wound-Poss.3sg

"head wound"

FUT.IMP = future imperative; GEN = genitive; IMP = imperative; INS = instrumental; INTENT = intentional; INTER.VB = interrogative verb; IPF = imperfect; IPF.CVB = imperfective converb; LOC = locative $; \mathrm{M}=$ masculine $; \mathrm{MDL}=$ modal MOD.CVB $=$ modal converb $;$ NFUT $=$ nonfuture; $\mathrm{NMLZ}=$ nominalizer; $\mathrm{NPST}=$ non-past $\mathrm{OBL}=$ oblique; $\mathrm{PL}=$ plural; $\mathrm{POSs}=$ possessive; $\mathrm{PRFL}=$ reflexive possessive; $\mathrm{PROG}=$ progressive; $\mathrm{PROP}=$ proprietive; $\mathrm{PRS}=$ present PRS.IMP $=$ present imperative; PST $=$ past PTL $=$ particle; $\mathrm{Q}=$ question particle; $\mathrm{R}=$ Russian (copy); SG $=$ singular; SIM.CVB $=$ simultaneous converb.

4. The transcriptions of published examples were modified slightly to be overall consistent; examples without glosses in the original sources were glossed by me. 
Interestingly, in Old Turkic these izafet constructions appear to have been quite frequently used alongside the genitival possessive constructions (3a, b; Doerfer 1988: 76). Furthermore, they are not semantically restricted to cases with generic possessors or part-whole relationships (Erdal 2004:381-382), but are used with specific possessors as well (3c, d).

(3) Old Turkic (Erdal 2004:381-382)
a. menin jutuz-um
1sG.GEN wife-Poss.1sG
"my wife"
b. biz-nin üzüt-ümüz
1PL-GEN souls-POss.1PL
"our souls"
c. beš teyri yarok-i
five god light-Poss.3sg
"the light of the fivefold god"
$\mathrm{d}$ Köl tegin atïs-ï (Yolluk tegin)
K. prince nephew-Poss.3sg (Y. prince)
"(Prince Yollug), the nephew of Prince Köl"

It thus appears that there was internal variation in the use of possessive constructions with a genitivally marked possessor and constructions with an unmarked possessor in an early stage of Turkic. Initially the variation appears to have been relatively free; at a later stage, however, conventionalization set in and in most modern Turkic languages led to a functional division of labor, with the genitive case being used for specific possessors, while the unmarked form is used for abstract, generic possessors. Sakha, however, did not follow the course taken by its linguistic relatives, but achieved conventionalization by choosing the construction with the unmarked possessor over the construction with the marked possessor; in the process, Sakha lost the genitive case. Although this choice of conventionalization process may have been the result of language-internal processes (cf. Croft 2000:178), some contact influence in the form of frequential copying may have played a role as well. This will be discussed in the following section.

\subsection{Possessive constructions in Siberian languages}

A survey of possessive constructions in the languages of northern Eurasia reveals considerable variation (Table 1). Languages differ both in whether the possessor is marked or not and in whether the possessum is marked or not, leading to four different types of constructions. 
Table 1. Types of possessor constructions in Siberian languages

\begin{tabular}{lll}
\hline & Marked possessor & Unmarked possessor \\
\hline Agreement with possessor & Turkic, Eskimo, (Selkup) & $\begin{array}{l}\text { Sakha, Tungusic, Mansi, (Khanty), } \\
\text { (Ket) }\end{array}$ \\
$\begin{array}{l}\text { No agreement with } \\
\text { possessor }\end{array}$ & $\begin{array}{l}\text { (Selkup), Mongolic, Chukchi, } \\
\text { Itelmen, (Ket) }\end{array}$ & Khanty), Yukaghir, Nivkh \\
\hline
\end{tabular}

Similar to what is found in the Turkic languages, both possessor and possessum are marked in Siberian Inupik Eskimo, in which the possessor carries the relative case suffix that also marks the agent of transitive constructions (Menovščikov 1980:56-57). In the Samoyedic language Selkup the possessum agrees with firstand second-person, but not with third-person, pronominal modifiers; agreement with nominal modifiers is optional (Bekker 1995:78, 82-83). In the Mongolic languages as well as the Chukotko-Kamchatkan languages Chukchi and Itelmen, the possessive relation is marked only on the modifier, with the head remaining unmarked (Kullmann \& Tserenpil 2001:79-81; Dunn 1999:148-151; Georg \& Volodin 1999: 92-98).

In addition to Sakha, languages in which the possessor remains unmarked are the Tungusic languages, the Finno-Ugric languages Mansi and Khanty, and the isolates Yukaghir and Nivkh. Of these, the head noun agrees in person and number with the possessor in the Tungusic languages (e.g. Nedjalkov 1997:158; Novikova 1960:141; Avrorin 1959:141; Nikolaeva \& Tolskaya 2001:480-482, Example 4a, b) and in Mansi (Riese 2001:25, 64-65, Example 5); in Khanty, agreement is triggered only by pronominal possessors (Nikolaeva 1999:52; Tereškin 1961:33-34, 44, Example 6).

(4) a. Evenki (Nedjalkov 1997:158)

ollomimni dzav-in

fisherman boat-Poss.3sG

"the/a fisherman's boat"

b. Nanay (Avrorin 1959: 141)

učenik daysa-ni

pupil book-Poss.3sg

"the pupil's book"

(5) Mansi (Riese 2001:25)

zum sa:yrap-e

man axe-Poss.3sg

"the man's axe" 
(6) Vakh Khanty (Tereškin 1961:44)

me rït-am

1 sg boat-POss.1sG

"my boat"

In Kolyma Yukaghir, although the head can take a possessive suffix, this does not agree with the possessor, but serves only to signal the relation between the head and the modifier (Maslova 2003:289-294). In Nivkh, possessive constructions with a nominal possessor generally consist of the apposition of unmarked nouns, while pronominal possessors are marked with an invariant suffix. Occasionally, this suffix is also attached to the possessor noun (Panfilov 1962:156-157, 252). In Ket, possessive constructions can consist either of a suffixally marked possessor and unmarked head, or of an unmarked modifier and prefixally marked possessum (7); marking on both modifier and head does not occur (Dulzon 1968: 74-75; Werner 1997: 112, 118-119).

(7) Ket (Krejnovič 1968:457)

ob de-qus'

father Poss.3sG.M-teepee

"father's teepee"

From the above discussion and Table 1 it becomes clear that northern Eurasian languages are split fairly evenly into those that mark possessive constructions on the head and those that mark them on the modifier. Not surprisingly, the two constructional variants that mark the relation only once, either on the head or on the modifier, are found more frequently than those that mark the possessive relation redundantly, on both head and modifier, or those that under-specify the relation. It is furthermore readily observable that the marking of the possessive relation only on the possessum is not a cross-linguistically favored construction.

While it is difficult to distinguish between internally motivated and externally induced changes without actual historical records, there are certain arguments that can be adduced in favor of one or the other explanation. A feature that is cross-linguistically very common is more likely to have developed from internally motivated changes than a cross-linguistically rare feature (Gensler 1993:33-34, 46). On the other hand, contact-induced changes frequently affect more than one feature of a given language, so that a postulated change is more plausible if other features can be shown to have undergone changes under contact influence from the same language.

While possessive constructions with an unmarked possessor are not particularly rare among the languages of northern Eurasia, they are also not the dominant construction type. There is thus no compelling evidence that would 
favor an internal change over an externally-induced change. On the other hand, Evenki shows the same pattern of possessive construction as that of Sakha, namely a marked possessum following on an unmarked possessor ${ }^{5}$; however, in contrast to Sakha, Evenki shares this pattern with other Tungusic languages and has thus probably inherited it from its ancestor. Furthermore, in addition to the loss of the genitive case as well as the development of the future imperative (see Section 5), Evenki contact influence has led to the development of an indefinite accusative meaning of the Sakha partitive case, the retention of a distinction between a comitative and an instrumental case, and pragmatic uses of possessive marking (Pakendorf 2007: 142-201, 208-270). The development in Sakha towards a construction that is cross-linguistically not overwhelmingly favored may well be due therefore to influence from Evenki, which is known to have been in contact with Sakha.

It may therefore be argued that the loss of the genitive in Sakha proceeded as follows: Sakha inherited variation between the genitivally marked and the unmarked possessive construction from its ancestor. After migrating to the north, speakers of Sakha came into contact with speakers of Evenki, a language in which the possessive construction generally consists of an unmarked possessor and marked possessum. This pattern resembled the constructional variant that was initially less frequently used in Sakha. Exposure to a language in which the construction with unmarked possessor is the norm led to an increase in the frequency of this construction and its gradual establishment as the default construction in Sakha. Thus, the interplay of initial language-internal variation and external contact influence led to the loss of the genitive case.

\section{The shift of local case-marking in Evenki}

\subsection{Local cases in Tungusic languages}

The Tungusic languages have a relatively large number of local cases that generally express stative location, motion towards, motion along, and motion from an object. Cases found in all the languages spoken on the Russian side of the Amur river, albeit not always with cognate suffixes, are the locative, allative, ablative, prolative, and elative; furthermore, the dative case has some local functions in all languages too. Evenki, however, differs from its sister languages in that the locative

5. Actually, the situation is somewhat more complicated in Evenki, since there exists a very rare alternative possessive construction in which the possessor is marked as well as the possessum (Pakendorf 2007:100-101).

(C) 2013. John Benjamins Publishing Company

All rights reserved 
case has lost its locative meaning; locative functions have been taken over entirely by the dative case. A closer look at the locative, allative, and dative cases in the Tungusic languages demonstrates that this change in Evenki may well be a further example of frequential copying. The following discussion will not take into account Manchu, which has undergone large-scale changes under the influence of Chinese and so lacks all the local cases with the exception of the ablative (Gorelova 2002:27-28).

In the Tungusic languages (excepting Evenki, which will be discussed below), the locative expresses stative location as well as the goal of movement $(8 \mathrm{a}, \mathrm{b})$; in Nanay, however, the locative case on its own is rarely used to express stative location, but is used in conjunction with postpositions for this purpose (Avrorin 1981: 173-181).

(8) Udihe (Nikolaeva \& Tolskaya 2001:521-522)

a. Udia namunka-da namu-lo bagdir-ti Udihe Oroch-FoC sea-LOC live-3PL "Udihe and Oroch people live on the sea"

b. zugdi-la iry-ki-ni house-LOC come-PST-3sG "He entered the house"

The allative case in these languages expresses the goal of motion (9). Thus, the locative overlaps in function with the allative. For some languages, a slight functional difference is postulated between the two overlapping allative meanings; in Udihe, for example, the allative is said to mark movement towards a goal, while the locative marks movement into a location (Nikolaeva \& Tolskaya 2001: 124).

(9) Nanay (Avrorin 1959: 182)

sikse bue klube-či ene-j-pu

evening 1PL club-ALL go-NPST-1PL

"In the evening we'll go to the club"

The dative case generally has a function of marking the recipient of an object (10a), but it also functions to express stative location (10b), thus overlapping with the locative case. For Udihe, a slight preference for the dative case to mark location "in" vs. the locative case to mark location "at" or "on" has been described (Nikolaeva \& Tolskaya 2001:125). There is thus a clear overlap in meaning in the Tungusic languages between the locative and allative case on the one hand, and the locative and dative case on the other, leading to variation in the use of casemarking to express the same functions. 
(10) Udihe (Nikolaeva \& Tolskaya 2001:524)

a. bi sin-du xeleba-wa bu-or-mi

1SG 2SG-DAT bread-ACC give-PST-1SG

"I gave you (some) bread"

b. Oroč (Avrorin \& Boldyrev 2001: 124)

sine me:ne dzurg-du-i bargdi-xa-ńi

mouse self house.OBL-DAT-3sg live-PST-3sG

"The mouse lived in her own house"

As mentioned above, Evenki differs from the other Tungusic languages in that the dative case has completely taken over the function of expressing stative location (11a), in addition to retaining its dative functions of marking recipients (11b; Nedjalkov 1997: 148, 169), while the locative case has shifted to marking only goals of motion (Nedjalkov 1997: 170, 11c). Thus, Evenki now has two allative cases, the allative and the locative, with a slight difference in use: the allative is used to mark general direction towards a goal that need not be reached (11d), while the locative case is used to mark the endpoint of direction.

(11) Evenki (Nedjalkov 1997: 169)
a. Turu-du dzav-du
Tura-DAT boat-DAT
"in Tura" "in the boat"

b. Evenki (Nedjalkov 1997: 148)

purta-va-s min-du bur-kel

knife-ACC-POss.2SG 1sG-DAT give-PRS.IMP.2SG

"Give me your knife"

c. Evenki (Nedjalkov 1997: 170)

atirkain dzu-la-vi yene-dzere-n

old.woman house-LOC-PRFL go-PRS-3SG

"The old woman is going to her house"

d. atirka:n dzu-tki-vi yene-dzere-n

old.woman house-ALL-PRFL go-PRS-3SG

"The old woman is going in the direction of/towards her house"

\subsection{Contact influence in Evenki?}

Clearly, Evenki has taken the existing variation in use between dative and locative, and between locative and allative, one step further than its sister languages. Although this may have been an independent development in Evenki, contact influence may have played a role too. This is shown by a survey of local case marking in Siberian languages (Table 2). 
Table 2. Cases involving goal and location in languages of northern Eurasia ${ }^{6}$

\begin{tabular}{llll}
\hline Language & Recipients & Goal & Location \\
\hline Old Turkic & Dative & Allative & Locative \\
Modern Turkic & Lative & & Locative \\
Ket & Lative, (Locative) & Locative \\
Mansi & Lative & Locative \\
Vakh Khanty & Lative & & Locative \\
Selkup & Lative & & Locative \\
Nganasan & Lative & & Locative \\
Itelmen & Lative & & Locative \\
Siberian Inupik & Lative & & Locative \\
Kolyma Yukaghir & Dative & Dative, Locative & Locative \\
Tungusic & Dative & Allative, Locative & Locative, Dative \\
Evenki & Dative & Allative, Locative & Dative \\
Sakha & Dative & & \\
Mongolic & Dative & & \\
\hline
\end{tabular}

*excluding Sakha

${ }^{* *}$ excluding Evenki

As can be seen in Table 2, it is rare to find syncretism involving stative location in the languages of northern Eurasia, since a separate case tends to be preserved to express locative meanings, even though dative and allative functions may be marked with only one case (cf. Pakendorf 2007: 122-139). Although early Old Turkic sources distinguish three cases, the allative, locative, and dative, the separate allative case is lost after the eleventh century, with the dative taking on the function of marking direction towards a goal (Erdal 2004: 171, 173, 177, 370-371). Most modern-day Turkic languages, with the exception of South Siberian Tuvan and Khakas (Anderson \& Harrison 1999: 14; Anderson 1998:6) as well as Sakha (see below) retain a distinctive locative case to express stative location, but have lost their separate allative case, with the dative case marking both dative functions of recipient and beneficiary and allative functions of the goal of movement (e.g. Kornfilt 1997:242-243). Other languages that possess a joint case to express dative and allative functions and a separate case for spatial location are Itelmen, Mansi,

6. For clarity's sake, I call all case-forms that mark both recipients and goals "lative" in Table 2, irrespective of the label given in the original source. 
Vakh Khanty, Selkup, Nganasan (though here the locative case also has instrumental meaning), and Siberian Inupik (Georg \& Volodin 1999:73-77; Riese 2001:25; Tereškin 1961:44-49; Kuznecova et al. 1980:178-181; Tereščenko 1979:82, 87; Menovščikov 1980:52-54). In Ket, the dative-allative case predominantly marks the goal of motion as well as recipients, while the locative predominantly marks stative location; however, the locative can occasionally also be used to mark direction (Werner 1997: 113-115; Dulzon 1968: 81-82). In Kolyma Yukaghir, both the dative and the locative can mark the goal of movement; however, the locative additionally expresses stative location, while the dative expresses recipients and beneficiaries (Maslova 2003: 96-98, 105-106).

An exception among the languages of northern Eurasia are the Mongolic languages, which have but one case to express dative, allative, and locative functions $(12 \mathrm{a}-\mathrm{c})$.

(12) Khalkha Mongol (Kullmann \& Tserenpil 2001:84)
a. Dulmar-d cay ög
D.-DAT tea give[ImP]
"Give Dulmaa some tea!"
b. bi Darxan-d am'dar-č baj-na
1sG D.-DAT live-SIM.CVB be-PRS
"I live in Darkhan"
c. ter öčigdör manaj-d ir-sen
3sg yesterday 1.POss-DAT come-PST
"Yesterday he came to my home"

Mongolic influence arguably led to the loss of the locative case in Sakha (Pakendorf 2007:139-141), which differs from its Turkic relatives in expressing dative, locative, and allative functions with just one case suffix, the Common Turkic dative case (13a-c). The influence of Mongolic languages on Sakha is detectable predominantly in the lexicon, with a large number of copied items deriving from Mongolic, including kin terms and a large number of verbs; furthermore, several Sakha suffixes were copied from Mongolic (Kałużyński 1962; Pakendorf \& Novgorodov 2009). However, Mongolic influence might also have played a role in the development of the locative case into a partitive case in Sakha (Pakendorf 2007: 168).

(13) Sakha (Pakendorf, narrative field data, 2002)
a. ol dje h-ol dzie-ni bisr ial-ga bier-de that well EMPH-that house-ACC one family-DAT give-PST.3SG "Well, he gave just that house to one family" 


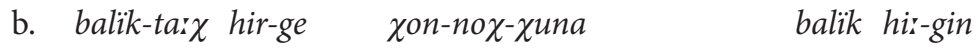
fish-PROP place-DAT spend.night-MDL-COND.2sG fish eat.PRs-2sG "When you spend the night in a place where there is fish, you eat fish"

c. onton fevral, mart ïj-tan töttörü ol beje-tin then February March month-ABL back that self-ACC.3sG dojdu-tugar muora-ya bar-ar, muora kitili-igar land-DAT.3sg sea-DAT go-PRs.3sg sea shore-DAT.3sG "Then in February, March (they) return to their home at the sea, by the sea-shore"

From the above discussion it is obvious that the languages of northern Eurasia are characterized by a separate locative case to mark stative location. Only a few languages stand out that have lost a separate case form for this function: these are first and foremost the Mongolic languages and the Turkic language Sakha. In addition, the distinction between individual local cases is blurred in the Tungusic languages, which show variation in case marking between the dative and locative, and the locative and allative, cases. However, only in Evenki has this variability led to a complete shift of locative marking to the dative case, with the Tungusic locative case suffix now marking only goals of motion. This shift may well have taken place as an independent internal innovation in Evenki. However, it is notable that speakers of Evenki dialects have been in contact with speakers of the Mongolic languages Buryat and Dagur as well as with speakers of Sakha, precisely those northern Eurasian languages which use the same case suffix to mark recipients as well as stative location. It is therefore quite probable that contact with languages that lack a separate locative case triggered the slight shift in usage patterns that ultimately led to the complete takeover of locative functions by the Evenki dative case.

\section{The fate of verbal subject agreement marking in Mongolic languages}

\subsection{Subject agreement marking in Mongolic languages}

Modern-day Mongolic languages differ in the extent of their verbal subject agreement marking: while more than half the languages, among them Khalkha Mongolian, completely lack verbal agreement (Sanžeev 1964:82-84; 14a-c), in several languages subject agreement is present to varying degrees $(15 \mathrm{a}, \mathrm{b})$. These are the Western Mongolic language Kalmyk, the Eastern Mongolic language Buryat, and the outliers Dagur, Moghol, Monguor, and Bonan (Weiers 1977:313). 
(14) Khalkha Mongol (Kullmann \& Tserenpil : 116)
a. minij a:v German jav-san
1sG.GEN father Germany go-PST
"My father went to Germany"
b. či jum id-sen ür?
2sG something eat-PST Q
"Have you eaten anything?"
c. Written Mongol (Poppe [1954] 1991:124)
bi nige šibayu ala-bai
1sG one bird kill-PST
"I killed a bird"

(15) Buryat (Poppe 1960:57)

a. "to go," indicative present

SG

PL

1 jaba-na-b

jaba-na-bdi

2 jaba-na-s

jaba-na-t

3 jaba-na jaba-na-d

b. (Skribnik 2003: 120)
bi tanai morj-irji xar-ar-b
1SG 2.PL.GEN horse-ACC see-IPF-1sG
"I saw your horse"

The languages which exhibit subject agreement differ in the type and extent of agreement: in Monguor and Bonan the agreement marking is rudimentary, with no distinction in number, and the distinction in person restricted to first vs. nonfirst (16); furthermore, the source of the agreement markers is unclear. These two languages will therefore be excluded from the following discussion.

(16) Bonan (Weiers 1977:321) “to sit," indicative present

$\begin{array}{lll} & \text { SG } & \text { PL } \\ 1 & \text { surdži } & \text { suidži } \\ 2 & \text { suidžo } & \text { surdžo } \\ 3 & \text { surdžo } & \text { surdžo }\end{array}$

In Kalmyk, Buryat, Dagur, and Moghol the verbal subject agreement suffixes are derived from personal pronouns, and they are obligatory in Buryat, Dagur, and Moghol (Weiers 1977:313). There thus exists a split among the very closely-related Mongolic languages between those lacking subject agreement marking on verbs and those in which such agreement marking is obligatory with suffixes derived from free personal pronouns. As will be argued here, the development of the verbal agreement system can be attributed to external contact influence acting on pre-existing internal variation, that is, to frequential copying. 
4.2 Historical variation and the impact of contact influence

In Written Mongol sources from the thirteenth to the beginning of the eighteenth century, postposed personal pronouns to mark subject agreement were optional (Poppe [1954] 1991: 124-125; Weiers 1977:295-296):

(17) Written Mongol, seventeenth to early eighteenth century (Weiers 1977: 295-296; original translation in brackets)
a. ta ene üge-ji jeki-n ögüle-mü

2PL this word-ACC inter.vB-MOD.CVB speak-PRS

"Why do you speak these words?" ("Was sprecht ihr diese Worte?")

b. jayun_du ire-bei či

what.for come-PST 2SG

"What have you come for?" ("Für was bist Du nun gekommen?")

c. Written Mongol, fourteenth-seventeenth century (Weiers 1977:296)

či nom-ijar amitan-i dzasa-mui či

2sG book-INS living.being-ACC put.in.order-PRS 2SG

"You bring the living beings to order through the law." ("Durch das Gesetz bringst die Lebewesen zur Ordnung du.")

Within the given period, there is no discernible diachronic tendency towards a decrease in subject agreement marking; rather, texts completely lacking postposed pronouns occur concurrently with texts showing a fair amount of subject agreement (Weiers 1977:307-309, 312). After the beginning of the eighteenth century, the use of postposed subject agreement marking in Written Mongol was entirely lost, a process suggested to have been the result of Tibetan influence (Weiers 1977:323). Tibetan, an isolating language, was the source language for the most important Buddhist texts which were published at that time (Janhunen 2003b: 32; Weiers 1986:41). Thus, translating texts written in an isolating language led to an increase in frequency of the unmarked verbal construction, which was already present in Written Mongol, until this became the only available construction - a clear example of frequential copying. Whether this frequential copying also played a role in the development of spoken languages such as modern-day Khalkha and Oirat, which completely lack subject agreement marking, is difficult to decide. While it is hard to imagine that changes in the written language would have been able to exert an influence on spoken languages in a time of restricted literacy, at the very least the tendency toward lack of verbal person agreement, which was clearly present in the Mongolic languages throughout their history, might have been accelerated by this influx of important translations from an isolating language.

The Mongolic languages in which the optional person marking has become obligatory, on the other hand, are in contact with languages that obligatorily mark subject agreement on finite verbs, so that the frequential copying here led to the 
opposite result from that found in Written Mongol. Thus, Moghol is spoken in Afghanistan in close contact with Indo-Iranian languages, and has undergone substantial change through contact influence in other domains of its grammar as well (Weiers 1977:312, 2003:248). Buryat and Dagur, on the other hand, although not spoken in geographical proximity to each other, are both spoken in the vicinity of different dialects of Evenki. Evenki is an agglutinative language with obligatory subject agreement marking on finite verbs $(18 \mathrm{a}, \mathrm{b})$.

(18) Evenki (Nedjalkov 1997:259, 244)
a. baka-dza-m baka-dza-nni
find-PRS-1SG find-PRS-2sG
"I find" "you find"
b. bi sine yene-b-dze-m
1sG 2sG.ACC go-CAUS-FUT-1sG
"I shall take you away"

Speakers of Evenki have shifted to Buryat, as documented by the existence of Buryat clan names of Evenk origin, as well as by phonological changes in Buryat that can be traced to Evenki influence (Cydendambaev 1981; Čimitdoržieva 2004); further Evenki influence on Buryat is discernible in the development of a future imperative in Buryat (see Section 5 below) as well as in the development of a system of syntactic reference tracking using person-marked converbs (Pakendorf 2010). It should be noted, however, that the influence exerted on the Mongolic languages by Evenki was only frequential, since Evenki subject agreement markers are not derived from personal pronouns. Thus, Buryat and Dagur did not copy the structure of Evenki subject agreement marking, but simply enhanced the frequency of the previously variable use of postposed pronouns until they became obligatory.

The possibility of marking subject agreement on verbs with postposed pronouns, which was present in the ancestors of Moghol, Buryat, and Dagur, was thus enhanced in frequency until it became the sole option when the speakers of these languages came into contact with speakers of languages with obligatory subject agreement. Further evidence that the finite person-marking in these languages developed out of the pre-existing historically documented variation is found in the fact that the modern-day languages differ with respect to which verbal suffixes occur with subject agreement markers. Thus, all three languages mark the subject on the imperfect/present, past tense, and future forms, which are found with optional person-marking in the historical sources as well. However, of two other historically used present tense forms (one a non-past, the other a narrative present), the narrative present is found with person-marking in Buryat, while the non-past takes person-marking in Dagur (Weiers 1977:314-318). 
This demonstrates that the possibility of indexing subject agreement on verbs, which was optionally present in historical Mongolic sources, has been enhanced through contact with languages in which such agreement is obligatory, but that the existing variation in use of person markers in the input may have resulted in differences in the outcome.

The preceding examples have illustrated how contact influence acting on language-internal variation can lead to changes in frequency of use of certain constructions. The following example presents a different kind of structural variation falling under the influence of a model language, resulting in contact-induced exaptation.

\section{The development of a future imperative in Sakha}

\subsection{The future imperative in the languages of Siberia}

In contrast to the other Turkic languages, Sakha makes a temporal distinction in the imperative mood, contrasting a full person-number paradigm of the immediate future imperative with a distant future imperative restricted to the second persons $(19 \mathrm{a}, \mathrm{b})$. The distant future imperative (which will be called "future imperative" in the following discussion for the sake of brevity) conveys commands that are to be fulfilled at a later point in time or after some other action; use of this form also considerably weakens the force of the command and it can thus be used as a polite imperative.

(19) Sakha (Pakendorf, elicited field data, 2002)
a. bergehe-yin ket,
tahïrça tïmnï: bayaji
hat-ACC.2sG wear[PRS.IMP.2sG] outside cold very
"Put on your hat, it's very cold outside!"
Sunday-DAT new dress-ACC.2SG wear-FUT.IMP.2SG PTL
"On Sunday wear your new dress, OK?"

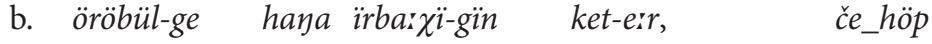

Contact influence appears to be responsible for the development of the future imperative, not only in Sakha but also in a number of other languages of Siberia. A survey of northern Eurasian languages (Pakendorf 2007:213-231) demonstrates that a temporal distinction in the imperative mood occurs very infrequently, with the majority of languages having only one imperative to convey commands (Table 3). 
Table 3. Distinction between present and future imperative in languages of northern Eurasia

\begin{tabular}{lll}
\hline Language (family) & Present imperative & Future imperative \\
\hline Turkic* & Full paradigm & \\
Sakha & Full paradigm & 2sG/2PL \\
Mongolic** & Full paradigm, several forms for 2sG/2PL & \\
Buryat & Full paradigm, several forms for 2sG/2PL & 2sG/2PL \\
Ket & 2sG/2PL & \\
Mansi & 2sG/2PL & \\
Khanty & 2sG/2PL & \\
Nganasan & 2+3sG/2+3PL, Hortative for 1sG/1PL & 2+3sG/2+3PL \\
Evenki & Full paradigm & Full paradigm \\
Ėven & Full paradigm & Full paradigm \\
Udihe & 2sG/2PL & \\
Nanay & full paradigm & 2sG/2PL \\
Yukaghir & full paradigm (excl 1sG) & 2sG/2PL \\
Chukchi & 2sG/2PL & \\
Itelmen & Full paradigm & \\
Nivkh & Full paradigm & \\
Eskimo & Full paradigm & \\
\hline
\end{tabular}

*excluding Sakha

${ }^{* *}$ excluding Buryat

The Northern Tungusic languages Ėven and Evenki make a temporal distinction in the imperative mood (20a-c), with a full paradigm for both present and future imperative.

(20) Ėven (Pakendorf, elicited field data, 2008)

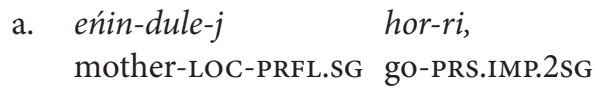
hin-u yaič-ad-da-n
2sG.OBL-ACC call-PROG-NFUT-3SG
"Go to your mother, she's calling you!"
b. tat-tịdji kiliep-u ga-na-na-nni
learn-ANT.CVB bread.R-ACC take-INTENT-FUT.IMP-2SG
"After school, go buy bread!"


c. Evenki (Nedjalkov 1997:262)

bira-va dag-mi guluvun-ma ila-da:-vi
river-ACC cross-SIM.CvB fire-ACC burn-FUT.IMP-PRFL.sG
"(Upon) crossing the river make a fire!”

The Southern Tungusic languages Nanay, Ulča, and Orok (which are very closely related to each other) have a future imperative, but this is restricted to the second persons. Among non-Tungusic languages other than Sakha, a distinction between present and future imperative is found in Yukaghir, Buryat, and Nganasan; however, in these languages the future imperative is restricted to the second persons (plus third person in Nganasan).

A temporal distinction in the imperative mood is quite rare world-wide (Schalley 2008:408-409; Gusev 2005:62), implying that contact influence may be a better explanation for its development and spread in northern Eurasia than independent internal innovations in these unrelated languages. Evenki and Even share the distinction between a present and a future imperative (though not the suffixes marking the future imperative) with some of their Southern Tungusic relatives, while Sakha is the only Turkic language, Buryat the only Mongolic language, and Nganasan the only Samoyedic language to make this distinction. It can therefore be argued that the direction of contact influence led from the Northern Tungusic languages to the non-Tungusic languages. This appears all the more plausible given the fact that Evenki and Ėven are or were in contact with all of the Siberian languages that now have a future imperative (Sakha, Buryat, Nganasan, and Yukaghir).

However, as can be seen from Examples (19b) and (20c), although Sakha copied the structural distinction, it did not copy the Evenki future imperative suffix: the suffix marking the Sakha future imperative is -Arr, while the Evenki suffix is $-d A$ : This Evenki influence on Sakha appears to have taken place in the absence of shift of entire groups of Evenki speakers to Sakha, since there is no genetic evidence for such an event (although intermarriage in the maternal line, i.e. with Evenki women, cannot be excluded). There is, however, genetic evidence for an initial migration of a very small group of Sakha ancestors to the north (Pakendorf et al. 2006); possibly their small numbers and economic vulnerability in the harsher climate of Yakutia made these immigrants initially dependent on their Evenki-speaking neighbors, leading to bilingualism by Sakha in Evenki (Pakendorf 2007:319-320).

In the following, I demonstrate that contact with Evenki may have led to the grammaticalization of the new future imperative out of a variant pre-existing in the Sakha ancestor. 
5.2 Grammaticalization out of a pre-existing periphrastic imperative form

In some Turkic languages there exists a periphrastic imperative form consisting of a converbal form of the lexical verb plus the auxiliary kör "to see" (21a, b). This periphrastic imperative is described as having different nuances of meaning in the modern languages, such as that of a request in Turkmen, expressing extremely important orders in Tartar, or a nuance of evil- or well-wishing in Uzbek (Ragimov 1966, cited in Korkina 1970:161). As seen in the examples, such forms are attested in Old Turkic as well.

Old Turkic (Erdal 2004:524)
a. jel-ü
kör
gallop-IPF.CVB see[Imp]
"See to it that you ride fast!"
b. saklan-u kör-gil
"Make sure that you take care!"
be.careful-IPF.CVB see[IMP]-EMPH

Although a periphrastic imperative of the kind found in other Turkic languages is not currently found in Sakha, such a form has been suggested by Böhtlingk ([1851] 1964:303) as the source of the Sakha future imperative. The grammaticalization path postulated by Böhtlingk (22) is based on an analytical imperative containing a consonant-final lexical verb, such as bar "to go":

\section{bara kör $\rightarrow$ barayar $\rightarrow$ bara:r}

The imperfective converb of consonant-final verbs in Sakha ends in a low vowel, thus giving bara kör for the hypothesized analytical imperative. In the process of grammaticalization, the lexical verb and the auxiliary must have fused, leading to a lenition of the intervocalic velar and assimilation of the final vowel to the vowel(s) of the lexical verb stem according to the vowel harmony rules operative in Sakha; the result would have been an intermediate form barayar. The lenition of intervocalic $-k$ - to $-\gamma$ - in such a grammaticalization process is not at all implausible: in modern-day Sakha, intervocalic $-k$ - regularly voices to $-g$-, $\mathrm{cf}$. bügün "today" < bu kün "this day," and -g-following on low vowels fricativizes, cf. kuoska-ya "cat-dat" vs. seri-ge "war-dat." Finally, at the end point of the grammaticalization process, the voiced velar fricative must have been dropped entirely, as is common in Sakha, both in fast speech phenomena and in the standard variants of the future indicative (e.g. bariayïm = barïam "I will go"), thus leading to the long low vowel characteristic of the Sakha future imperative (cf. Böhtlingk [1851] 1964:303). 
It should be noted, however, that this grammaticalization process can account only for the development of the future imperative suffix for consonant-final verbs, since the imperfective converb of vowel-final verbs ends in a long high vowel, e.g. ornńo: $\rightarrow$ ornńu: "to play $\rightarrow$ playing." A verb form ending in a long high vowel cannot be the initial source for the long low vowel characteristic of the future imperative. However, it is quite plausible that in this case analogical leveling took place, especially since a number of high-frequency verbs that in addition function as auxiliaries end in consonants, e.g. kel "come," bar "go," olor "sit," tur "stand," sit "lie (down)," utuj "sleep," and is "go."

The development of the Sakha future imperative would thus have proceeded as follows: Speakers of Sakha were in contact with speakers of Evenki, and bilingual individuals were familiar with the structures of Evenki. One of the distinctions made by Evenki, which was not made by the ancestral Sakha language, is a distinction between an imperative form to mark commands that are to be fulfilled immediately and a form to mark commands that are to be fulfilled at a later point in time. Ancestral Sakha had an imperative construction used for immediate commands (i.e. for one side of the Evenki distinction); it also had a periphrastic imperative construction with a pragmatic function. This periphrastic imperative construction came to be identified with the future imperative used by speakers of Evenki, and this "interlingual identification" (Weinreich 1953:7-8) triggered the further grammaticalization process in Sakha, for which the existing variant of the periphrastic construction provided the substance. This ultimately led to Sakha acquiring the same temporal distinction in the imperative mood as that found in Evenki. Thus, the interplay of internal variation and contact influence in this case drove the grammaticalization of the future imperative suffix in Sakha. As will be discussed below, this is analogous to (language-internal) "exaptation" (Lass 1988) and can therefore be considered "contact-induced exaptation."

\section{Discussion and conclusions}

As the preceding examples demonstrate, the interplay of language-internal variation and external contact-induced change is an important factor in language change. However, contact influence does not always need to be invoked as an explanation of the observed changes. As Croft (2000:100-102, 176-186) argues, potential ambiguity is always inherent in the presence of competing structural variants with the same or very similar meanings, and consequently speech communities tend to try to increase the conventionality of constructional variants in order to facilitate communication. He mentions three (language-internal) mechanisms by which speakers can increase conventionality: (1) Over time, the variants can achieve a 
functional division of labor, with a slightly different function assigned to each; as discussed in Section 2.1, this is the path taken by most modern Turkic languages in resolving the variation between possessive constructions with genitivally marked and unmarked possessors. (2) The variants can acquire a social meaning and thus achieve a socially conditioned division of labor, with one form being used by one speech community (and potentially marking identity with that group), while the second variant is used by another community. (3) One of the variants can be chosen over the other, thereby increasing in frequency and in time possibly being retained as the sole construction. In Croft's theory, this process of shift in frequency is brought about through the selection of one of the variants over the other through repetition of this variant in successive utterances by speakers. This selection can and does, of course, take place in monolingual communities without any external influence; in this case variants might get used more frequently because they are initially used by speakers with a certain amount of social prestige in the community.

It is thus not always clear whether observed shifts in frequency of usage patterns can really be ascribed to contact influence, or whether they might not be the result of language-internal processes alone; in addition, language-internal and contact-induced processes may go hand in hand, leading to changes in the same direction. For example, the shift towards use of the dative case as the sole marker of stative location in Evenki might well have been due to purely internal developments, independent of any external contact influence. One argument in favor of internal development is the fact that in the South Tungusic language Nanay the locative case is already rarely used by itself to mark stative location, but generally occurs in this function together with postpositions. However, even if Evenki might in time have undergone the shift towards dative-marked location by itself, contact influence arguably led to an acceleration of the process. This is evidenced by the fact that Evenki, which is spoken in contact with Mongolic languages and Sakha, is the sole Tungusic language to have completed such a shift; the Mongolic languages and Sakha, however, are the exceptions amongst languages of northern Eurasia in that they do not have a separate case suffix to mark stative location.

One means of distinguishing independent shifts in frequency of use from shifts triggered by contact influence is to examine the cross-linguistic pattern of usage of the variants under investigation. The reasoning behind this approach is that cross-linguistically frequent constructions might have some inherent features that make them easier to process, thus providing an internal stimulus for selection of that particular variant over the other. This is the approach followed in this paper: The fact that in northern Eurasia there is no cross-linguistic favoring of possessive constructions with an unmarked possessor, of marking stative location with the same case that marks recipients, or of a temporal distinction in the imperative mood, was taken as an indication that contact with languages in which the 
previously less frequently used variant is the norm triggered or accelerated the shift in usage patterns towards that variant.

Another point that emerges out of the examples discussed here is that there are two different ways in which language-internal variation coming under the influence of a contact language can lead to change. One is a shift in frequency of use of variant constructions, as discussed by Johanson (2002:306), Aikhenvald (2002:238), and Heine \& Kuteva (2005:44-62), exemplified by the examples in Sections 2-4. In these cases, two variants of a construction exist side by side and fulfill roughly the same function, such as the variation in possessive constructions documented in Old Turkic, the variation in local case functions in the Tungusic languages, and the variation in subject agreement marking on finite verbs in historical Written Mongol texts. In such cases, a shift in frequency of use leads to the establishment of one variant over the other as the norm within the speech community - without, however, leading to any change in meaning. The other way in which internal variation can interact with contact influence is by providing the material for contactinduced grammaticalization, or "contact-induced exaptation," as exemplified by the development of the future imperative in Sakha discussed in Section 5. In this case, the initial variation involved constructions with a somewhat different meaning and function, so that resolution of the variation did not involve the selection of one variant over the other with the same result in meaning; rather, in this case the pre-existing variation provided the material from which the new imperative form could be grammaticalized. Thus, such instances of language-internal variation can play an important role in contact-induced change by providing the material basis for grammaticalization to act upon, thereby offering an alternative to copying of actual form-meaning pairs from the model language.

As noted, the second type of interplay of language-internal variation with contact influence can be analyzed as "exaptation" (Lass 1988). ${ }^{7}$ Exaptation is the process by which existing forms are taken over to fulfill different functions from their original ones. Lass introduced the term in a fairly strict sense, calling exaptation "...the opportunistic cooptation of a feature whose origin is unrelated to its subsequent use" (Lass 1988:34, emphasis mine). This strict sense of the term does not apply in the case of the Sakha imperative, since the material that was co-opted to create the future imperative was already in use as an imperative construction. However, if we define exaptation as a process by which constructions can take on a different function from the one they had initially, irrespective of whether the new function is related to the old one (i.e. if we use the term exaptation with a broader meaning than that initially intended by Lass), then we do observe the co-optation

7. I thank a participant at the workshop on "Language contact and morpho-syntactic change" for bringing this to my attention.

(C) 2013. John Benjamins Publishing Company

All rights reserved 
of a pre-existing form to fulfill a new function: a periphrastic construction with a pragmatic function was taken over to create a temporal distinction between a present and a future imperative. Croft (2000:126-130) calls the process that underlies (language-internal) exaptation "hypoanalysis." In hypoanalysis, speakers reinterpret a meaning assigned to a particular form by the context in which it (habitually) occurs as being inherently associated with the form itself, that is, they reinterpret a contextual meaning as being coded by the specific form. In situations of language contact, bilingual speakers reinterpret the meanings of forms not on the basis of the context in which they occur, but on the basis of their perceived correspondence to a form in the model language, that is, by "interlingual identification" (Weinreich 1953:7-8). In this line of argument, it is not the meaning derived from the context in habitual use of a construction that is reanalyzed as being inherently coded by the construction itself; rather, the identification of the recipient language variant with the model language construction leads to its reanalysis. This can therefore be called "contact-induced exaptation."

This paper has shown that language-internal variation can play a large role in language change, not only through internally conditioned developments, but also through the interaction with a contact language. Such contact-induced changes of variable constructions can lead to shifts in usage patterns on the one hand and to the grammaticalization of new constructions on the other. Although it would be too strong a statement to claim that language-internal variation is a necessary prerequisite of contact-induced change - obviously, languages very frequently copy forms they lack - it is clearly a very important factor. This holds especially for language-contact situations in which copying of actual substance is eschewed on social grounds.

\section{References}

Aikhenvald, A.Y. 1996. Areal diffusion in northwest Amazonia: the case of Tariana. Anthropological Linguistics 38: 73-116.

Aikhenvald, A.Y. 2002. Language Contact in Amazonia. Oxford/New York: Oxford University Press.

Aikhenvald, A.Y. \& Dixon, R.M. (eds). 2006. Grammars in Contact - A Cross-Linguistic Typology. Oxford: Oxford University Press.

Alekseev, A.N. 1996. Drevnjaja Jakutija - Zheleznyj vek i époxa srednevekov'ja. [Ancient Yakutia: The Iron Age and the Medieval Epoch]. Novosibirsk: Izdatel'stvo Instituta Arkheologii i Etnografii SO RAN.

Anderson, G.D.S. 1998. Xakas. Munich/Newcastle: LINCOM Europa.

Anderson, G.D.S. 2006. Towards a typology of the Siberian linguistic area. In Linguistic Areas. Convergence in Historical and Typological Perspective, Y. Matras, A. McMahon \& N. Vincent (eds), 266-300. New York: Palgrave Macmillan.

Anderson, G.D.S. \& Harrison, K.D. 1999. Tyvan. Munich/Newcastle: LINCOM Europa.

(C) 2013. John Benjamins Publishing Company

All rights reserved 
Atknine, V. 1997. The Evenki Language from the Yenisei to Sakhalin. In Northern Minority Languages. Problems of Survival. Papers Presented at the Eighteenth Taniguchi International Symposium: Division of Ethnology, H. Shoji \& J. Janhunen (eds), 109-121. Osaka: National Museum of Ethnology.

Avrorin, V.A. 1959. Grammatika nanajskogo jazyka. Tom pervyj. [A grammar of Nanay. Vol. 1]. Moscow/Leningrad: Izdatel'stvo Akademii Nauk SSSR.

Avrorin, V.A. 1981. Sintaksičeskije issledovanija po nanajskomu jazyku. [Studies of Nanay syntax]. Leningrad: Nauka.

Avrorin, V.A. \& Boldyrev, B.V. 2001. Grammatika oročskogo jazyka. [A grammar of the Oroč language]. Novosibirsk: Izdatel'stvo SO RAN.

Bekker, Ė.G. 1995. Morfologija sel'kupskogo jazyka. Južnye dialekty. [The morphology of Selkup. Southern dialects]. Tomsk: Tomskij gosudarstvennyj pedagogičeskij institut.

Bodrogligeti, A.J.E. 2003. An Academic Reference Grammar of Modern Literary Uzbek. Munich: LINCOM Europa.

Böhtlingk, O.N. [1851] 1964. Über die Sprache der Jakuten. The Hague: Mouton \& Co.

Buraev, I.D. \& Šagdarov, L.D. 2004. Obrazovanie burjatskogo jazyka. [The formation of the Buryat language.]. In Burjaty, L.L. Abaeva \& N.L. Žukovskaja (eds), 227-232. Moscow: Nauka.

Čimitdoržieva, G.N. 2004. Vlijanie tunguso-mančžurskikh jazykov na burjatskie govory [The influence of Tungus-Manchu languages on Buryat dialects]. In Istorija i vnešnie svjazi burjatskogo jazyka [The history and external contacts of the Buryat language], 96-107. Ulan-Ude: Izdatel'stvo Burjatskogo naučnogo centra SO RAN.

Croft, W. 2000 Explaining Language Change - an Evolutionary Approach. Harlow: Pearson Education.

Cydendambaev, C.B. 1981. Zametki ob etničeskikh i jazykovykh kontaktakh burjat i evenkov [Notes on the ethnic and linguistic contacts of the Buryats and Evenks]. In Jazyki i fol'klor narodov severa [Languages and folklore of the peoples of the north], 70-91. Novosibirsk: Izdatel'stvo "Nauka," Sibirskoe otdelenie.

Doerfer, G. 1988. Grammatik des Chaladsch. Wiesbaden: Otto Harrassowitz.

Dulzon, A.P. 1968. Ketskij jazyk. [The Ket language]. Tomsk: Izdatel'stvo Tomskogo Universiteta. Dunn, M.J. 1999. A Grammar of Chukchi. Ph.D. dissertation, Australian National University.

Erdal, M. 2004. A Grammar of Old Turkic. Leiden, Boston: Brill.

Gensler, O.D. 1993. A Typological Evaluation of Celtic/Hamito-Semitic Syntactic Parallels. Ph.D. dissertation, University of California at Berkeley.

Georg, S. \& Volodin, A.P. 1999. Die itelmenische Sprache. Wiesbaden: Harrassowitz Verlag.

Gogolev, A.I. 1993. Jakuty. Problemy ètnogeneza i formirovanija kul'tury. [The Yakuts. Problems of their ethnogenesis and the formation of their culture]. Yakutsk: Izdatel'stvo JaGU.

Gorelova, L.M. 2002. Manchu Grammar. Leiden/Boston/Köln: Brill.

Gumperz, J.J. \& Wilson, R. 1971. Convergence and creolization. A case from the Indo-Aryan/ Dravidian border in India. In Pidginization and Creolization of Languages. Proceedings of a Conference held at the University of the West Indies, Mona, Jamaica, April 1968, D. Hymes (ed.), 151-167. Cambridge: Cambridge University Press.

Gusev, V.J. 2005. Tipologija specializirovannykh glagol'nykh form imperativa [A typology of specialized imperative verb forms]. Ph.D. dissertation, Institut jazykoznanija RAN.

Haase, M. 1992. Sprachkontakt und Sprachwandel im Baskenland. Die Einflüsse des Gaskognischen und Französischen auf das Baskische. Hamburg: Helmut Buske Verlag.

Heine, B. \& Kuteva, T. 2005. Language Contact and Grammatical Change. Cambridge: Cambridge University Press. 
Janhunen, J. 1996. Manchuria. An Ethnic History. Helsinki: The Finno-Ugrian Society.

Janhunen, J. 1998. Ethnicity and language in prehistoric Northeast Asia. In Archaeology and Language II: Correlating Archaeological and Linguistic Hypotheses, R. Blench \& M. Spriggs (eds), 195-208. London/New York: Routledge.

Janhunen, J. 2003a. Proto-Mongolic. In The Mongolic Languages, J. Janhunen (ed.), 1-29. London/New York: Routledge.

Janhunen, J. 2003b. Written Mongol. In The Mongolic Languages, J. Janhunen (ed.), 30-56. London/New York: Routledge.

Johanson, L. 1999. The dynamics of code-copying in language encounters. In Language Encounters across Time and Space. Studies in language contact, B. Brendemoen, E. Lanza \& E. Ryen (eds), 37-62. Oslo: Novus Forlag.

Johanson, L. 2002. Contact-induced change in a code-copying framework. In Language Change: the Interplay of Internal, External, and Extra-Linguistic Factors, M.C. Jones \& E. Esch (eds), 285-313. Berlin/New York: Mouton de Gruyter.

Johanson, L. 2008. Remodeling grammar: Copying, conventionalization, grammaticalization. In Language Contact and Contact Languages, P. Siemund \& N. Kintana (eds), 61-79. Philadelphia: John Benjamins.

Kałużyński, S. 1962. Mongolische Elemente in der jakutischen Sprache. Warsaw: Panstwowe Wydawnictwo Naukowe/The Hague: Mouton \& Co.

Korkina, E.I. 1970. Naklonenija glagola v jakutskom jazyke. [Verbal moods in Yakut]. Moscow: Izdatel'stvo "Nauka."

Kornfilt, J. 1997. Turkish. London, New York: Routledge.

Krejnovič, E.A. 1968. Ketskij jazyk [The Ket language]. In Jazyki narodov SSSR [Languages of the peoples of the USSR], 453-473. Leningrad: Izdatel'stvo "Nauka," Leningradskoe otdelenie.

Kullmann, R. \& Tserenpil, D. 2001. Mongolian Grammar. Ulaan Baatar: Academy of Sciences, Institute of Language and Literature.

Kuznecova, A.I., Khelimskij, E.A. \& Gruškina, E.V. 1980. Očerki po sel'kupskomu jazyku. [Sketches of Selkup]. Moscow: Izdatel'stvo Moskovskogo universiteta.

Lass, R. 1988. How to do things with junk: exaptation in language evolution. Stellenbosch Papers in Linguistics: $33-61$.

Maslova, E. 2003. A Grammar of Kolyma Yukaghir. Berlin/New York: Mouton de Gruyter.

Matras, Y. \& Sakel, J. (eds). 2007. Grammatical Borrowing in Cross-Linguistic Perspective. Berlin: Mouton de Gruyter.

Menovščikov, G.A. 1980. Jazyk eskimosov beringova proliva. [The language of the Bering Strait Eskimos.]. Leningrad: Izdatel'stvo "Nauka," Leningradskoe otdelenie.

Nedjalkov, I. 1997. Evenki. London: Routledge.

Nikolaeva, I. 1999. Ostyak. Munich: LINCOM Europa.

Nikolaeva, I. \& Tolskaya, M. 2001. A Grammar of Udihe. Berlin/New York: Mouton de Gruyter.

Nimaev, D.D. 2004. Načalo formirovanija ètničeskogo jadra burjat. [The beginning of the formation of the ethnic core of the Buryats.]. In Burjaty [The Buryats], L.L. Abaeva \& N.L. Žukovskaja (eds), 13-25. Moscow: Nauka.

Novikova, K.A. 1960. Očerki dialektov èvenskogo jazyka. [Sketches of Even dialects]. Moscow, Leningrad: Izdatel'stvo Akademii Nauk SSSR.

Pakendorf, B. 2007. Contact in the Prehistory of the Sakha (Yakuts): Linguistic and Genetic Perspectives. LOT Dissertation Series 170. Utrecht: LOT.

Pakendorf, B. 2010. Contact in Siberian Languages. In The Handbook of Language Contact, R. Hickey (ed.), 714-737. Oxford: Blackwell Publishing. 
Pakendorf, B., Novgorodov, I.N., Osakovskij, V.L., Danilova, A.P., Protod'jakonov, A.P. \& Stoneking, M. 2006. Investigating the effects of prehistoric migrations in Siberia: genetic variation and the origins of Yakuts. Human Genetics 120: 334-353.

Pakendorf, B. \& Novgorodov, I.N. 2009. Loanwords in Sakha (Yakut), a Turkic language of Siberia. In Loanwords in the World's Languages. A Comparative Handbook, M. Haspelmath \& U. Tadmor (eds), 498-524. Berlin: Mouton de Gruyter.

Panfilov, V.Z. 1962. Grammatika nivkhskogo jazyka. Čast' 1. [A grammar of the Nivkh language. Part 1]. Moscow: Leningrad: Izdatel'stvo Akademii Nauk SSSR.

Poppe, N.N. 1960. Buriat Grammar. Bloomington: Indiana University/ The Hague: Mouton \& Co. Poppe N.N. [1954] 1991. Grammar of Written Mongolian. Wiesbaden: Otto Harrassowitz.

Ragimov, M.Š. 1966. Istorija formirovanija naklonenij glagola $v$ azerbajdžanskom jazyke. [The history of formation of the verbal moods in Azerbaijani]. Baku (cited from Korkina 1970).

Riese, T. 2001. Vogul. Munich: LINCOM Europa.

Ross, M. 1996. Contact-induced change and the comparative method: cases from Papua New Guinea. In The Comparative Method Reviewed. Regularity and Irregularity in Language Change, M. Durie \& M. Ross (eds), 180-217. New York/Oxford: Oxford University Press.

Sanžeev, G.D. 1964. Sravnitel'naja grammatika mongol'skikh jazykov: Glagol [A comparative grammar of the Mongolic languages. The verb]. Moscow: Nauka.

Schalley, E. 2008. Imperatives: a Typological Approach. Ph.D. dissertation, University of Antwerp. Skribnik, E. 2003. Buryat. In The Mongolic Languages, J. Janhunen (ed.), 102-128. Routledge Language Family Series. London/New York: Routledge.

Sovremennyj kazakhskij jazyk. Fonetika i Morfologija. 1962. [The modern Kazakh language. Phonetics and Morphology]. Alma-Ata: Izdatel'stvo Akademii Nauk Kazakhskoj SSR.

Tereščenko, N.M. 1979. Nganasanskij jazyk. [The Nganasan language]. Leningrad: Izdatel'stvo "Nauka," leningradskoe otdelenie.

Tereškin, N.I. 1961. Očerki dialektov khantyjskogo jazyka. [Sketches of Khanty dialects.]. Moscow/Leningrad: Izdatel'stvo Akademii Nauk SSSR.

Thomason, S.G. \& Kaufman, T. 1988. Language Contact, Creolization, and Genetic Linguistics. Berkeley/Los Angeles/Oxford: University of California Press.

van Coetsem, F. 1988. Loan Phonology and the Two Transfer Types in Language Contact. Dordrecht: Foris Publications (cited from Winford 2005).

Weiers, M. 1977. Typen verbaler Personendifferenzierung im Mongolischen. Central Asiatic Journal 21: 295-325.

Weiers, M. 1986. Zur Herausbildung und Entwicklung mongolischer Sprachen. In Die Mongolen. Beiträge zu ihrer Geschichte und Kultur, M. Weiers (ed.), 29-69. Darmstadt: Wissenschaftliche Buchgesellschaft.

Weinreich, U. 1953. Languages in Contact - Findings and Problems. New York: Publications of the Linguistic Circle of New York, No. 1.

Werner, H. 1997. Die ketische Sprache. Wiesbaden: Harrassowitz Verlag.

Winford, D. 2005. Contact-induced changes. Classification and processes. Diachronica 22(2): 373-427.

Wurm, S.A. 1996. Map 109: Distribution of ethnic groups and languages in Siberia in the mid20th century. In Atlas of Languages of Intercultural Communication in the Pacific, Asia, and the Americas, S.A. Wurm, P. Mühlhäusler \& D.T. Tryon (eds). Berlin/New York: Mouton de Gruyter. 
Appendix 1. Genealogical affiliation and geographic location of the languages discussed in the paper.

\begin{tabular}{|c|c|c|}
\hline Language & Family & Location \\
\hline Sakha (Yakut) & Turkic & NE Siberia \\
\hline Dolgan & Turkic & Taimyr Peninsula \\
\hline Old Turkic & Turkic & S Siberia/Central Asia \\
\hline Turkish & Turkic & Anatolia \\
\hline Uzbek & Turkic & Central Asia \\
\hline Kazakh & Turkic & Central Asia \\
\hline Evenki & Northern Tungusic & E Siberia \\
\hline Ėven & Northern Tungusic & E Siberia \\
\hline Nanay & Southern Tungusic & Lower Amur \\
\hline Ulča & Southern Tungusic & Lower Amur \\
\hline Orok & Southern Tungusic & Sakhalin \\
\hline Udihe & Southern Tungusic & Sihote-Alin \\
\hline Oroč & Southern Tungusic & Sihote-Alin \\
\hline Buryat & Eastern Mongolic & S Siberia \\
\hline Khalkha & Eastern Mongolic & Mongolia \\
\hline Kalmyk & Western Mongolic & S Russia \\
\hline Dagur & Mongolic outlier & Inner Mongolia \\
\hline Monguor & Mongolic outlier & N China \\
\hline Bonan & Mongolic outlier & N China \\
\hline Moghol & Mongolic outlier & Afghanistan \\
\hline Written Mongol & Mongolic & Central Asia (only written) \\
\hline Khanty & Uralic (Finno-Ugric) & W Siberia \\
\hline Mansi & Uralic (Finno-Ugric) & W Siberia \\
\hline Selkup & Uralic (Samoyedic) & W Siberia \\
\hline Nganasan & Uralic (Samoyedic) & Taimyr Peninsula \\
\hline Ket & Yeniseic & W Siberia \\
\hline Chukchi & Chukotko-Kamchatkan & Chukotkan Peninsula \\
\hline Itelmen & Chukotko-Kamchatkan & Kamchatkan Peninsula \\
\hline Siberian Inupik & Eskimo-Aleut & Chukotkan Peninsula \\
\hline Kolyma Yukaghir & Yukaghir & NE Siberia \\
\hline Nivkh & Isolate & Amur river mouth/Sakhalin \\
\hline
\end{tabular}

